\title{
A stranger in a strange land
}

\section{Bill Bryson's latest journey takes him through the unfamiliar world of science.}

\author{
A Short History of Nearly \\ Everything \\ by Bill Bryson \\ Doubleday: 2003. 528 pp. $£ 20$ \\ Broadway: 2003. $\$ 27.50$
}

\section{Walter Gratzer}

This is what Bertrand Russell wrote about his omnivorous friend, Aldous Huxley: "You could tell by his conversation which volume of the Encyclopaedia Britannica he'd been reading. One day it would be Alps, Andes and Apennines, and the next it would be the Himalayas and the Hippocratic Oath." A similar, if a little more circumscribed, social accomplishment can be yours if you last the pace with the irrepressible Bill Bryson in this canter through the landscape of science and its historical roots.

Let it be said at once that Bryson's is a truly remarkable achievement. He was awakened, as he tells it, from a state of unblemished and tranquil ignorance, while looking out of an aeroplane window, by a spasm of curiosity about the nature of the world beneath, not to mention the skies above and the Universe beyond. From this damascene moment sprang the extravagant ambition to acquaint himself with the entirety of science and interpret it to the citizenry at large. $\mathrm{He}$ accordingly immersed himself, if his bibliography is anything to go by, in a formidable course of study, but more than that, he approached many scientists, hooked his finger in their buttonholes and did not let go until he had got from them all he wanted. Bryson was surprised and delighted to find that most of them were willing, even eager, to talk to him at length about their work. His quest took him three years.

As aficionados of his travel writing will know, Bryson is quick - some might say profligate - with the catchy trope and the arresting analogy. So, the diameter of an atom is to a millimetre as a sheet of paper is to the height of the Empire State Building; if the Earth were an apple, the deepest holes yet sunk by geologists would still not begin to penetrate the skin; and if you could retreat through time at the rate of one year per second it would take you three weeks to arrive at the emergence of humans, but twenty years to reach the Cambrian, the period of the Burgess Shale fossils. (Do I hear the creak of mouths falling open?)

It is easy to discern where Bryson's enthusiasms have chiefly settled. He is best on biology, especially evolution and palaeontology, and also on geology and on the cosmos. $\mathrm{He}$ waxes lyrical on the numberless riches in the caverns of the Natural History Museum

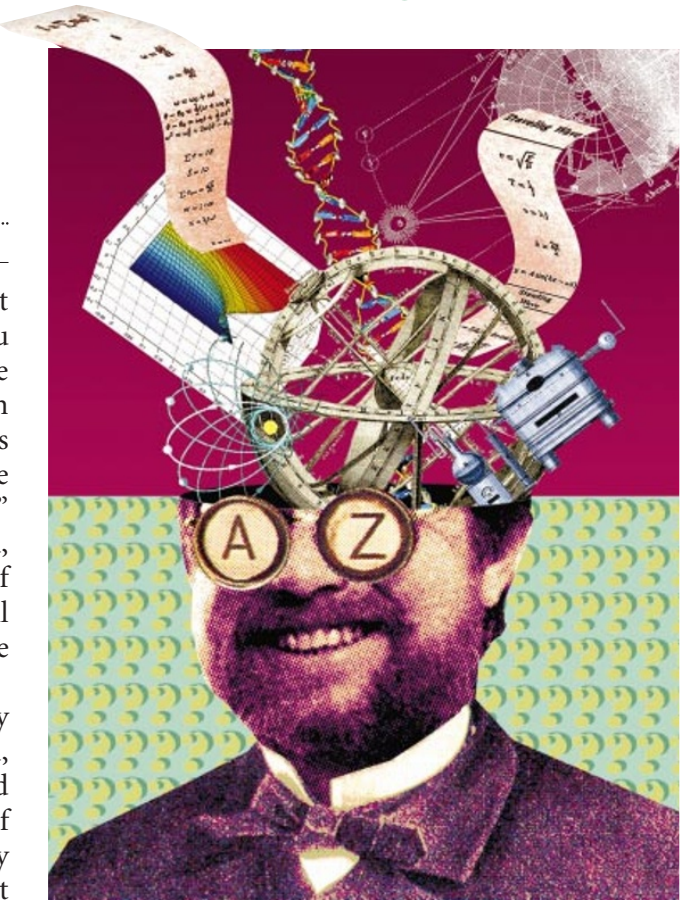

Lavoisier's career and death on the scaffold, and reveals that the lineaments of a statue erected in his honour a century later were in fact those of another victim of the Terror, Condorcet, recycled by the sculptor. This is diverting enough, but tells us little about the unparalleled magnitude of Lavoisier's achievements. The egregious Count Rumford gets a walk-on part, and it is pleasing to learn that he achieved immortality by inventing thermal underwear and the drip coffee-maker, but what about his observations in the cannon-boring works, which disposed of the caloric theory of heat, just as Lavoisier consigned phlogiston to oblivion?

There are, inevitably in a work of such scope, some errors of fact, and (more seriously) a few of comprehension. What is one to make of the assertion that "oxygen itself is not combustible", whereas hydrogen gas "is extremely combustible"? Or that in outer space, "each molecule is very

in London, perhaps because he found there a genial host, the matchless Richard Fortey, author of captivating books on trilobites and the history of life on Earth. Fortey guides him through labyrinthine disputes about events that happened 500 million years ago, and through the ill-natured conflicts between the rival evolutionists Stephen Jay Gould, Richard Dawkins and Simon Conway Morris, and the gaffes that characterized the interpretation of the Burgess Shale fossils.

Bryson laments with Fortey the fading of classical taxonomy. There are said to be fewer than 20 taxonomists in Britain now to patrol an endless frontier, with some 15,000 previously unrecognized species surfacing each year in the literature; in the nineteenth century - the golden age of taxonomy they would all have been subjected to minute scrutiny, sometimes close on a lifetime's work. In all, the proportion of the planet's species so far recognized is (depending on whom you believe) somewhere between $2 \%$ and $12 \%$ (and in the case of bacteria and viruses, well below 1\%). It is sad when the world's only expert on a genus of bryophytes, say, heads for retirement or the grave - he is irreplaceable. Yet Bryson does not altogether explain why the effulgent new layer of understanding exposed to view by genomic analysis might not be considered more exciting and more pressing than classical morphology.

Bryson's grasp is somewhat less secure when it comes to the basics of the physical sciences. He relates the circumstances of warm". And when the sun is hot on your back, Bryson says it's the impact of "excited atoms" that you are sensing - so what of radiant heat?

But one can readily forgive a man such lapses who can sum up the state of cosmology thus: "The upshot of all this is that we live in a universe whose age we can't quite compute, surrounded by stars whose distances we don't altogether know, filled with matter we can't identify, operating in conformance with physical laws whose properties we don't truly understand.'

Bryson's brief valedictory chapter is about what humans are doing to our planet. Over the aeons of biological time, he tells us, one life form, on average, vanished every four years; now the rate of extinction of species resulting from human activities exceeds this by a factor of 120,000. Man, as Julian Huxley expressed it, has become the cancer of the Earth.

The last man who was said to know the whole of science was the Victorian savant William Whewell. Bryson would make no such claim for himself, and indeed is modest about his learning, but he has shown that science - most of it, at any rate - is accessible to an outsider equipped with a decent measure of curiosity and some staying power. His is a bravura performance, which will give much pleasure, and I salute it.

Walter Gratzer is emeritus professor of biophysical chemistry, King's College London, the Randall

Centre, Guy's Campus, St Thomas' Street,

London SE1 1UL, UK. 